\title{
Framing Opposition to Nuclear Power: The Case of Akkuyu in Southeast Turkey
}

\author{
Pinar Temocin
}

Following the 2010 nuclear deal between Russia and Turkey, several consequent revelations of administrative deficiencies in the Turkish nuclear program, the Fukushima accident, and waste issues all spurted widespread protests across Turkey. This study analyzes how groups opposing nuclear power plants have framed the Akkuyu nuclear project as a dangerous, risky, disadvantageous, and irrational policy choice. Through analysis of empirical data from a range of sources such as in situ observation, semi-structured interviews, articles, and websites, the study considers the core issues raised and arguments given by the opponents.

Keywords nuclear energy, anti-nuclear movements, opposition, civil society, Turkey

\section{Introduction}

One of the most important transformative actions planned by the current government of Turkey since the 2002 victory of the Justice and Development Party (AKP) formed by Recep Tayyip Erdogan is a renewed emphasis on nuclear projects. Among these is the Akkuyu nuclear power plant (NPP) in the southern province of Mersin on the Mediterranean coast of Turkey. The site had been selected as far back as 1976, but no work was done, and the project was cancelled due to the lack of sufficient resources in 2000. An agreement in 2010 between the Turkish government and Russia's largest electricity generating company, Rosatom, allowed the project to resume. Construction was formally launched in 2015 and effectively began in 2018.

The 2010 agreement was elaborated and emphatically presented in 2010 by the then Prime Minister (now President) Erdogan in the context of the "2023 vision," which is full of goals for the prosperity and economic independence of Turkey. The agreement with Russia, however, has led to intense conflicts and protests, and this issue has polarized the supporters (energy policy makers, 
local investors, and experts and engineers involved with the project) and the opponents (activists from environmental organizations, civilians, associations, municipalities, and unions), and has created an intense debate. While the Turkish government persistently maintains the plausibility of the project, there have been a considerable number of disputes over its underlying feasibility caused by technological, political, economic, and management problems. This has resulted in the undermining of its legitimacy and growing public opposition to nuclear development.

In practice, opposition to Turkey's first nuclear power plant has been framed in a number of different ways since 2010, of which the following are the most important: (1) an approach based on risk factors with a "what-if" perspective which hints at the probabilities in the event of an accident; (2) a grievanceoriented approach, which is homogeneously and innately embedded in the specific characteristics of the project; (3) a political dimension which emerges due to the Turkish government's economic and development discourses regardless of the majority's consent; (4) consequence-driven concerns which have been revived after Fukushima with its interpretation for the Turkish case; and (5) alternativefocused claims which are shaped by a "why-not" perspective that highlights other energy production alternatives.

This article analyzes these diverse opposition arguments. The accumulation and interaction of these claims can shed light on civil society motivations and preferences concerning the energy-policy making culture. Their very diversity, however, points to a potential difficulty in coordinating the messages and actions of opposition groups.

\section{Method and Theory}

This study provides an overview of the origins and strategies of Turkey's antinuclear activism. It does not seek an objective assessment of the factual bases of their positions, but rather analyzes their choices in how to represent the problem and what solutions to seek. It focuses throughout on "how" instead of "why," and analyzes the link between synchronous variables and a longer-term sociohistorical perspective in shaping the strategy of anti-nuclear groups. Looking to the contemporary period, I ask: "how are the existing arguments given by antinuclear movement formed and sustained," and "how are the objects, subjects, and actions of the anti-nuclear groups constructed." In a longer-term perspective, the questions become "what are the characteristics of the Akkuyu project that made opponents particularly anxious about it," and "how can we explain the phenomenal rebirth of anti-nuclear activism with several distinct arguments in a specific timeframe (2010-2015)." In both cases, the focus of the study is the subjective representations of the problem and its possible solutions produced by 
the activist groups themselves.

While there is little written in the scientific literature pertaining to the Akkuyu project, there is an enormous amount of primary material written by the advocacy groups consisting of reports, articles, opinion pieces, social media posts, and blogs, etc., available at present. This study is based on these primary materials both in Turkish and English. Empirical data was accordingly collected from a range of sources: in situ observation, semi-structured interviews $(\mathrm{N}=18)$ lasting from thirty minutes to one hour with activists and representatives of anti-nuclear groups, newspaper articles, websites, blogs written by activists, NGO reports and statements, and ethnographic research in the village where the Akkuyu NPP is located. The face-to-face interviews were conducted in Akkuyu, Mersin, and Istanbul in February-March 2016; others were conducted via email, Skype, and social networks. The overall material is supplemented by secondary literature both on anti-nuclear activism and on the role of civil society groups in politics more generally.

The interpretation of this material rests first of all on the method of frame analysis, focusing on the intentional ways in which activists construct their self-presentations, interpretations, and counterarguments toward a specific social problem in order to receive attention and support from others. This is complemented by the theory of political opportunity structures to provide an understanding of the existing conditions, settings, and actions that determine a social movement's characteristics and trajectory. This helps understand the relationship between collective protests and political systems, prevalent demand, and institutional responses (providing avenues and tolerance to movements).

A useful starting point for understanding the diverse strategies of antinuclear groups is Schön and Rein's (1994) discussion of "framing." According to these authors, intractable policy controversies are often characterized by the presence of antagonistic actors who struggle to legitimate their actions and ideas through gaining control over the definition of policy objects in order to shape actions for their own benefit. "Elements" are selected for attention to construct a specific "problem" out of a complex reality or vague situation (ibid., 26). Framing policies are based on conflictual dialogues for designing a policy; thus, actors are considered as policy-designers seeking to transform policy objects, solve problems, resolve dilemmas, or exploit existing opportunities in order to bring about desirable consequences (design rationality). Applying this perspective to social movements, we can see that anti-nuclear organizations and actors in movements try to frame the main problem so that it can be solved through advantageous strategies.

When it comes to addressing global challenges, framing is critical for public understanding so that they can build consensus, participate in in mobilizations, and form trust in activist agendas. If the framing of a particular issue succeeds in addressing existing conditions, it can influence public opinion and eventually lead 
to government actions coherent with activist demands. For this reason, Snow and Benford (2000) argue that the struggle over the production of ideas and meanings is essential. Attributing a meaning to collective actions, expressing grievances or the issue at stake in line with its level, and sharing a common identity (based on a "we" and "our" approach) as part of the component of collective motivation are important elements in framing complex issues such as opposition to nuclear development.

In order to provide a broader description of how "anti-nuclear activism" is framed and structured by groups, we need to analyze the way they act toward this issue. Guigni (1998) argues that social movements, particularly when they express themselves through their most typical forms of action (such as public demonstrations, protests, and lobbying) address their message simultaneously to two distinct targets, power holders and the general public, as message receivers. They press the political authorities in order to be recognized as well as to get their demands met. In other words, they seek support and try to sensitize the population to their cause (ibid., 26). In this sense, their arguments for meeting their demands are significant elements. According to Pianta, Ellersiek, and Utting (2012), who research the dynamics of activism on global issues in Europe and its impact on policies, political opportunities as well as "internal" dimensions of activist organizations and networks are related to issue framing which is based on public understanding and perception; the building of consensus, with the support of public opinion as well as public participation in mobilizations; and the legitimation and recognition of activists' role in social issues. Furthermore, a desired change can happen when strong and feasible demands find political space with the support of multiple actions at multiple levels (ibid., 524). Thus, it is important to see the interaction between civil society organizations and the nuclear policy making-process. In this sense, framing is helpful to shape discourses and portray causes of social movements appeal to a wide audience.

The evidence presented in this article makes it clear that, even for activists who are on the same side of an issue, in this case opposed to construction of the Akkuyu NPP, the key elements of the situation can be framed quite differently. This observation fits well with observations of other scholars. McCarthy and Zald (1977) suggest that there is always enough discontent in any society to supply grassroots support for a movement when it is effectively organized. Therefore, major catastrophes function as a "suddenly imposed grievance" that can generate immediate protests and mobilization (Walsh 1981). In this case, framing is thus provided by an outside event. By itself, however, this cannot explain the variety of strategies observed. Even in a case such as the Chernobyl accident, definitions and interpretations differed widely from one setting to another (Koopman and Duyvendak 1995, 241). For these authors, the explanation for protest behavior lies in the accumulated presence of intolerable circumstances, unbearable deprivations, and intense grievances. Catastrophes, in this argument, interact 
with context; even following a discrete event such as the Chernobyl accident, different settings, claims, and political contexts (such as governmental support and skepticism over the nuclear future) play an important role in framing the "problem" (ibid., 237). In this regard, the work of Martin (2007) expands the explanation of strategic actions based on the negative overall image of nuclear energy produced by its opponents.

Bringing these approaches together, it is clear that while arguments made by anti-nuclear groups are likely to combine reference to specific events such as reactor accidents with longer-term issues (disposal of high-level waste, cancers from radon released by uranium tailings, increased risk of terrorism, promotion of a regional nuclear arms race, and economic subsidies for nuclear power, etc.) and the way in which any given group does this will depend on elements beyond the nuclear issue itself. The notion of a political opportunity structure helps us understand why this is so. In this context, Tilly $(1998,496)$ points out that intrinsic elements of social movements can be claimed (by sympathizers) as the presence of solidarity, the construction of shared identities, the sense of common grievance, the creation of sustainable organizations, and more. In this logic, collective protest occurs when activists blame the political or economic system in place for the problems they denounce, believing that an opportunity to bring about change exists when protests take place (Della Porta and Diani 2006, 18). In this way, the openness and accountability of political systems play a role not only in the success or failure of any movement but also in the tactics they employ. For Kitschelt (1986), the role of the national political structure is essential for movements' strategic choices and outcomes. In this line, "the openness of a political regime to new demands" plays a substantial role.

Between them, framing and opportunity structures provide analytical tools for understanding the differences between the messages and strategies of the various anti-nuclear groups in Turkey. While the first encourages us to look at how each of them defines the problem to be addressed, the second helps us to understand why some solutions and strategies are given priority.

\section{State and Society in Contemporary Turkey}

Before looking at the specific issues raised by anti-nuclear activists, it is important to take into account two elements of context: the place of the Akkuyu project in the Turkish government's larger plans for economic and political development, and the background for social activism in contemporary Turkey.

The Akkuyu project is presented by the Turkish government as part of a broader program for Turkey's economic development. The " 2023 vision," marking the centenary of the proclamation of the Turkish republic, has been put forward by the government as a comprehensive vision for the long-term 
renovation of Turkey's place in the world, in terms of economy, technology, as well as infrastructure for communication, transport, tourism, and energy. In the name of a "New Modern Turkey," the program aims to achieve some particular targets with mega-projects such as the world's busiest airport and intercontinental bridges in order to become one of the ten most powerful countries. The Akkuyu nuclear project as part of this aim is strategically planned to begin operation in 2023 with the intention of symbolizing Turkey's nuclear industry, economic power, and technology capability. Beyond its symbolism, the project is justified by the government in the context of eliminating energy dependency and diversifying energy generation to contribute to the aim for economic growth.

Somewhat ironically in light of the government's rhetoric of independence, the Akkuyu project is made possible by the support of a foreign partner, the 2010 contract with Rosatom. According to this deal, the Akkuyu NPP will be built, owned, and operated by Russia. According to the Nuclear Energy Project Implementation Department, the logic for the agreement with Russia is based on its nuclear capacity and technology. Russia has been generating electricity through NPPs since the 1950s. Furthermore, Turkey seems to rely on Russia and Rosatom's reputation on the global market for the ongoing construction of NPPs in other countries. In return, Russia's stake in the project is at least 51 percent according to the agreement, with the remaining shares available for sale to outside investors. This opens a door to Turkish and international investors and companies and can be seen as part of a broader effort by the government to attract international capital.

Relations between the state and civil society in Turkey have varied considerably over the last decade. The government initially took important steps towards democratization and liberalization of the economy after gaining the majority in the 2002 election in order to improve the climate for accession to the European Union (EU). It provided a space for state-civil society relations and organizations (Ozcetin and Ozer 2015). The state-civil society dialogue became restricted, however, after the political awakening of civil society over the Gezi Park protests in the second half of 2013. Since then, there has been growing miscommunication between Turkish civil society and the current state which rejects the legitimacy of protests and increasingly has suppressed them with force. The newly created disparity resonates in almost all spheres of civic activities including those made by anti-Akkuyu project groups.

\section{Opposing the Akkuyu Nuclear Power Plant}

The nationwide anti-nuclear movement began in the mid 1970's and gained strength after events such as the Chernobyl nuclear accident and the energy project with Russia. It consists of organizations, individuals, and independent 
activists, including unions, associations, municipalities, members of political parties, environmentalist non-governmental organizations (NGOs), ecologist initiatives, left-wing movements, journalists, celebrities, nuclear engineers, intellectuals, and academics. The anti-nuclear movement rejects the idea that nuclear energy is reliable, clean, or affordable, a position consistently defended by the ruling party's representatives. Organizations such as Nukleer Karsiti Platfom (with a broad alliance of diverse groups that bring together over 100 components such as NGOs, labor and trade unions, trade associations, and chambers), Greenpeace Mediterranean (as a recognized transitional organization which advocates for the end of the nuclear age by means of phasing out existing reactors and rejecting any new construction of commercial nuclear reactors, as well as stopping international trade in nuclear technologies and materials), and subgroups of The Greens have fought against Turkey's nuclear aspirations and taken action together and separately to tackle this issue with deepening objections. Others include Kuresel Eylem Grubu (Global Action Group), which is based on collective activism on ecology, more specifically global warming and nuclear energy, and Nukleersiz.org, which is an online project initiated by eminent activists.

To achieve their demands and gain recognition, social movement actors have pressured national and local governments through press statements, signature campaigns, and petitions, etc. Governmental officials and investors, on the other hand, seem determined to build the NPP and are certain about its technological safety systems. As these groups have been playing an antagonist role in the process of nuclearizing Turkey, they have called on the government to renounce their attempt to build the first NPP (and potential future plants) and demanded possible safer sustainable alternatives. However, the government seems to be sticking to their nuclear agenda despite the intensifying nuclear debate since 2010. There are several contested factors in having an "anti-nuclear" approach when considering the devastating effects of any nuclear power in the world. But for the Akkuyu nuclear project, the most relevant factors are based mainly on the nature of the project itself.

\section{Risk-Based Explanations}

Anti-nuclear groups anywhere in the world discuss the risks of an accident in terms of environment, health, safety, and security with respect to past nuclear tragedies or potential ones (Martin 2007, 45). With respect to the Akkuyu project, safety and security related concerns have resonated the most in terms of riskiness of the project.

One of the major catalysts of the movement against the Akkuyu NPP relates to safety and security precautions. The nuclear industry's security program is 
regulated by the Turkish Atomic Energy Authority (TAEK), which is responsible for the adequacy of Akkuyu's security system (TAEK 2012). Despite this, antinuclear groups have raised questions on nuclear security since the beginning of the agreement in the context both of natural disasters and human attack. The concerns that have been raised in this context are discussed here.

\section{Seismic Risks}

The argument given by the pro-nuclear side just after the Fukushima disaster has been based on the facts that it was an old plant and the earthquakes and tsunamis of the sort that occurred in Fukushima or anywhere in Japan are much less common in Turkey. Even so, scientific findings demonstrate that an earthquake can destroy the whole project as Akkuyu is located in an earthquakeprone area. Correspondingly, Greenpeace claims that the Ecemiş fault line is situated just $25 \mathrm{~km}$ away from the Akkuyu NPP site (Greenpeace 2011). Turkey is also considered one of the most seismically active regions in the world (Nuclear Power Daily 2009). When considering seismic hazards analyses and technical evaluations of the project, building a nuclear reactor next to the Ecemiş fault zone where seismic activity could increase the risk of an accident that could affect the entirety of Southern Turkey, Cyprus, and the Middle East is not acceptable for the opponents of the project.

\section{Potential Terrorist Activities}

Physical security of NPPs and their vulnerability to deliberate acts of terrorism was elevated to a security concern following the terrorist attacks of September 11, 2001 (Holt and Andrews 2014). Therefore, the relationship between the real and imagined risks should be taken into consideration when studying possible nuclear terrorism or military attack. A successful attack on the Akkuyu NPP could have devastating consequences in light of its geopolitical position in the region. How will the region defend itself given the possibility that an air attack might penetrate the Akkuyu plant when considering that Turkey's nuclear partner Russia is a growing power in the Middle East? The question on "how will the Turkish authorities protect civilians' to right to life, public safety, and national security" is framed by engineers from anti-nuclear groups.

\section{Dissemination of Nuclear Weapons}

The close relationship between nuclear power and nuclear weapons provides an additional element in framing the problem. In this context, opposition to the Akkuyu plant is based on being the first step on a path toward nuclear weapons, as it is believed that nuclear power increases the risk of nuclear proliferation due to the production of raw nuclear material (Udum 2010, 204). The possibility of the dissemination of nuclear weapons in the Middle East has been raised by the anti-nuclear physicists affiliated with anti-nuclear groups which argue that 
any country that has nuclear power has the potential to make nuclear weapons (Campaign for Nuclear Disarmament 2006).

Turkey does not have its own nuclear weapons. However, the country hosts more than sixty American nuclear weapons at Incirlik Air Force Base (EDAM $2012,4)$. As the Akkuyu NPP is planned to be constructed very close to Incirlik, the question of whether or not the Akkuyu NPP would create a new "Incirlik Base" for Russia is unavoidable considering that Rosatom owns nuclear weapons and that Russia has security interests in Syria, South Cyprus, and Israel. Moreover, the Russian-designed Akkuyu NPP will be the first and only plant in a state's sovereign territory that is owned and operated by another state. Giving such priority to Russia creates anger beyond the core of anti-nuclear groups because of fears that Turkey's dependency will increase and Russia will become autonomous via Akkuyu, like America's Incirlik Airbase in Adana. It could also be argued that Russia is trying to augment its nuclear energy programs in the Middle East to neutralize the influence of the United States in this region (Trenin 2016). As a consequence, one line of anti-nuclear arguments made by one of the most wellknown electrical engineers from Nukleersiz.org, Arif Kunar, focusses on the claim that Turkey has been picked as a guinea pig for this role in the strategybased game (Interview, Arif Kunar, July 12, 2016). In this way, and in the context of the Iranian nuclear program, the principal risk is of a regional nuclear arms race, which would also decrease future security for the region. When considering that Turkey might be ready to have its own nuclear weapons through using the material from an NPP, which is also not far from Incirlik and Iran, the risk of a nuclear arms race becomes a powerful frame for anti-nuclear activism.

\section{No Trust in Rosatom}

For Akkuyu, one of the main questions over security and safety issues creating dissonance is based on the Russian State Atomic Energy Corporation, Rosatom. Since the company belongs to the same group as the builders of the Chernobyl reactor, Rosatom itself is seen as a risk factor for the Akkuyu project. The concerns over Rosatom are based on its bad image after Chernobyl, its use of obsolete technology, especially the reactor type chosen for Turkey (VVER-1200), doubt about Rosatom's technical competence, and the skills of their technical staff. There are further concerns about Russia's domination in the Middle East.

Rosatom has set the agenda of building four VVER-1200 nuclear reactors, but has never reviewed nor assessed the license application (Yeşil Gazete 2015). Hence, TAEK is finding it difficult to procure technical support services. The questions over the reactor type include whether or not it will succeed as a new reactor. Turkey will also not have the authority to review the design. Moreover, with questions over low-quality materials, human resources capacity, and insufficient information, the company itself is a problematic issue for the opponents of the project. According to the agreement, Rosatom is responsible 
for engineering, construction, operation, and maintenance of the plant. A Greenpeace Hungary (2014) report emphasizes that Rosatom is continuing to operate Soviet-era reactors despite the demonstrated failure of Chernobyl, even though the company claims that they have improved the safety of their reactors. According to the report, concerns raised by the anti-nuclear movements around the world are based on quality control. In the anti-nuclear consensus, safety risks raise a serious question as to whether it would be plausible to approve Rosatom's ambition in owning and operating an NPP in Turkey, which has no experience in nuclear energy nor a sophisticated nuclear safety culture.

In addition to safety issues in the legacy of Chernobyl, the Russian nuclear industry does not have a good reputation in the eyes of opponents because of corruption. The question of "how sure can we be about Turkey in this sense after all of the scandals involving Rosatom" lies at the center of concerns about Rosatom, which is facing charges of corruption, fraud, and supplying cheap nuclear materials (Digges 2013).

For all these reasons, anti-nuclear groups blame Turkish nuclear decisionmakers for making an agreement with Russia without learning from history. A "build-own-operate" nuclear project, which is the model being discussed with Russia, would be a disastrous choice for Turkey in their view. The Russian nuclear industry and regulatory authority lack transparency. According to engineering experts watchdogging the Akkuyu project since the beginning, they have neither the capacity nor the willingness to enforce the rules and regulations set out in their own nuclear safety codes (Interview, Hayrettin Kilic, April 16, 2016).

\section{Grievance-Oriented Explanation of Opposition to the Akkuyu Project}

Distinct from questions of technical or political risk are direct grievances linked to the normal operation of the plant. Here the focus is on the project's overall cost, lack of waste management, and problems in administration. These grievances are emphasized by the anti-nuclear groups in defense of their claim that the project as a whole is not acceptable.

\section{Cost and Economic Irrationality}

Another important issue with nuclear plants is the question of financial cost. The total installation of the Akkuyu NPP is estimated at $\$ 20$ billion. Electricity will be produced by Rosatom. After the completion, the company will sell electricity to Turkey at a fixed price of $\$$ USD 12.35 cents per $\mathrm{kWh}$ in the first fifteen years after the NPP starts operating. It is assumed that this price will pay back the investment expenditures of Rosatom in the given time (World Nuclear Association 2018). The opponents of the project claim that it is an exceptional deal with Russia due 
to the amount. In one of the most popular Turkish newspapers, columnist Yalçın Doğan (2015) indicated that "in Western countries, a kWh of electricity produced in NPPs costs between 4 and 4.5 cents; however, in Akkuyu, it will be 12.35 cents. It is the most expensive electricity in the world after Japan." It is true that the price will be costly for prospective electricity consumers in Turkey. Looking at France ( 8.97 cents) and the United States (9.43 cents) we see that their national electricity prices in 2015 were below than estimated electricity price for Akkuyu (Statistic Portal 2015). Adding to the installation cost, electricity price is expected to be very high when producing electricity.

Furthermore, when also looking at renewable energy sources as attractive alternatives in the eyes of opponents, wind and solar energies are less costly than nuclear power (DeRosa 2015). Considering that there are no economic benefits from the Akkuyu project, the ambition for the project sounds economically irrational as well as controversial. Accordingly, a central claim made by the antinuclear groups is that a nuclear reactor in Akkuyu will not benefit Turkey. Rather it will produce profits for Russia but will increase electricity prices in Turkey while increasingly binding Turkey to Russia.

\section{Lack of Appropriate Management: Waste Disposal}

Radioactive waste management is one of the most crucial issues for any country employing nuclear energy. The case of Akkuyu differs from the conventional discourses. The discovery of radioactive and toxic waste buried in western Turkey (in Gaziemir, Izmir) in 2012 revealed the neglect of the TAEK's energy approach. The Ministry of Environment and Urban Planning, the Izmir Municipality, and the Gaziemir District Governor's Office knew about the radioactivity and none of the agencies took any steps to punish anyone for negligence. Although this is a fundamental element of managing any nuclear project, the Environmental Assessment Report does not contain any information about managing and disposing nuclear waste (Atici 2015). It matters for the anti-nuclear groups that even this vital report for the project keeps the "waste issue" secrect. This has embroiled the project in juridical struggles.

Furthermore, it has been argued by environmental activists that having nuclear waste without having an NPP reveals the officials approached this issue apathetically. One possibility is that nuclear waste is being imported illegally into Turkey by foreign companies who also operate nuclear plants. In any case, the discovery of radioactive waste buried at an abandoned factory brought additional and specific attention to this issue.

\section{Lack of Appropriate Administration: ÇED report}

An Environmental Impact Assessment Report (a.k.a. ÇED) is required in Turkey for all projects of this kind. Rosatom applied to receive ÇED approval for Akkuyu. However, only ten days were given to the public to review the contents and details 
of the report totaling 3,500 pages. The report was immediately approved by the Ministry of Environment and Urbanization in December 2014. As analyzed by Demircan (2015), this report was approved both hastily and carelessly with no public participation in a non-transparent process. There was backlash for the trivialization of such an environmental issue and, thus, environmental activists and anti-nuclear lawyers revealed, on online platforms, deficiencies and missing elements (such as the lack of liability in case of an accident) based on nuclear waste and its environmental risk factor-analysis. The legality and legitimacy of the report subsequently was thrown into doubt. Additionally, the signatures of engineers in the report had been forged (Radikal 2015). The former Minister of Environment and Urban Planning of Turkey denied all of the allegations. The question of "how is it possible to ignore these forged signatures" became an important subject (Interview, Filiz Yavuz, August 4, 2016).

There were seventeen lawsuits filed by several advocates in 2014. One interviewee, Green Party Lawyer Arif Ali Cangi, who was involved in these lawsuits stated that "this insufficient report (ÇED) was found unnecessary by the authorities when applying the report for decontamination of Gaziemir where nuclear waste was found" (Interview, Arif Ali Cangi, April 23, 2015). The nuclear waste is a crucial matter and it needs special attention. Even if all the measures by authorities are taken in advance, the report fails to address the environmental impacts of the nuclear reactors and gives no information about accident risks in the event of an earthquake. Also, as for accidents in general, no one knows who will take responsibility. According to the major Turkish environmental group TEMA, the report is not professional with respect to environmental issues given its disregard for any seismic or accident risk and waste management, as well as emergency protective action plans (TEMA 2014). Therefore, a number of demonstrations were organized by the anti-nuclear groups requesting an adequate review of the report. To this date, however, the objections of numerous citizens' initiatives (such as the Ege Environment and Culture Platform and Sinop's Friends of the Environment Group) against the ÇED report have been ignored by the Turkish authorities.

An additional reason to doubt the seriousness of the environmental impact report is that Greenpeace Mediterranean published pictures of construction in 2014. The construction of the first NPP had therefore started before the approval of the ÇED report. That is to say that construction had started without proper authorization and having a construction license. In this way the standard legal procedure was ignored. This contested report has contributed significantly to transforming Turkey's nuclear struggle at least in part into a legal battle. In addition to the underlying risk and dissatisfaction associated with the project, questions over the legality of the government's reporting on it has become a central source of grievance. 
Figure 1. Image from Greenpeace Mediterranean Showing Unlicensed Construction of the Nuclear Power Plant in 2014

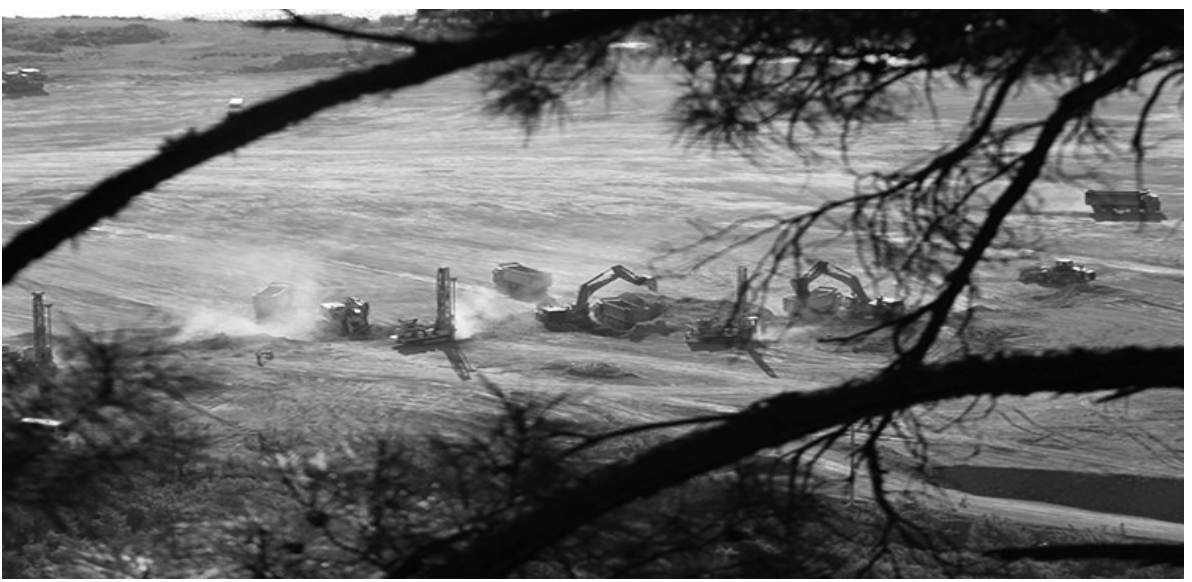

Source: Greenpeace (2014a)

\section{Opposition to the Akkuyu Project for Political Reasons}

Since the 2010 agreement with Russia, the Akkuyu process has been more politicized through focusing on the rhetoric of "development" by means of technology and economy (Interview, Fikret Ataman, March 5, 2016). The nuclear power issue in Turkey today is a technical necessity in the eyes of proponents, whereas opponents consider it a "political choice." The government makes use of arguments that shape public perception on behalf of development such as increased employment, independence, advanced technology, and a newly developed Turkey, etc. By building the tools of development with profit-driven outcomes such as economic growth and scientific progress, modern societies are creating their own threat through producing new forms of risks (Beck 1999 as cited by Jarvis 2007). For the case of Akkuyu, with economy-oriented policymaking and national prestige considerations hanging over energy production, the nuclear issue in Turkey is more politicized than ever. The techno-economic progress and nuclear decision-making culture, which is committed to the country's development and further economic success, is pushing acceptance of nuclear energy through a hegemony of experts and political actors.

Nuclear power is a centralized power source in both a physical and political sense. It allows a small number of scientific, political, and economic elites to make key decisions about energy. It is not surprising that governments, nuclear engineers, and scientists are in favor of nuclear energy in technical terms. Through having control over technical resources, Turkey's nuclear debate has 
created an antipathy toward "nuclear technologies." In the eyes of anti-nuclear activists, technocratic nuclear decisions are necessarily "uninspiring" and "undesirable" ones. In this view of large-scale technologies as well as technologyfriendly economic growth, it is believed that "zero risk does not exist" even if using the highest forms technology, as proved by Fukushima (Greenpeace 2014a).

According to the TAEK, one of the driving forces for addressing security concerns and advancing a domestic nuclear infrastructure is to enhance the use of products of nuclear technology by acquiring it for the benefit of Turkey. Anti-nuclear activists reject this argument, however, asserting instead that this technically-oriented approach to future national well-being causes the perceived erosion of democracy by increasing political ignorance. In respect to the antinuclear claim, nuclear decision-makers are sacrificing human life for economic benefits (Interview, Filiz Yavuz, March 6, 2016).

Along with the relationship between technocratic decisions underlying risk factors, there is also a question of democracy for the opponents of the Akkuyu project. The non-democratic structure of Turkish policy-making, with its topdown structure, is based on political repression, exclusion, non-integration, and division between authoritative politicians and the electorate. Turkish democracy's deficiency in affecting the nuclear decision is illustrated by the government's opponents using the following arguments.

First, the responsible bodies do not consider providing sufficiently systematic and holistic information to public. The nuclear vendors do not share any of the public's concerns. They refuse to answer any question associated with the disadvantageous, dangerous, or risky parts of the project. The attitude of the Public Information Center in Mersin (Interview in situ, February 24, 2016), for example, was one of certainty in all aspects of the project, denying all scientific explanations inconsistent with their point of view, and responding to any contrary findings and allegations through praising the nuclear project. This approach does not give any space for a questioner to evaluate the project further. Even the ÇED report portrayed the project as essential to the contemporary Turkish pursuit of wellbeing, regardless of an uncompleted and technically undetailed assessment, which was elaborated hastily without considering several crucial issues for the current and future nuclear posture. This does not enable the populace to ensure their constitutional rights to live in a healthy and balanced environment (Interview, Filiz Yavuz, March 6, 2016).

Second, there is neither public participation in nor democratic consultation with the government. In other words, there is a lack of mutual engagement between the local community and energy policy-makers. Stronger involvement of civil society requires greater inclusion of civil society in the decisionmaking process (Netzer 2011, 9). In the case of Turkey in the energy policy implementation phase, public participation in a decision, which concerns all citizens, is virtually non-existent (Interview, Sebahat Arslan, February 24, 2016). 
No one has consulted the public during the decision-making or implementation phases to obtain their opinion. On these grounds, dissatisfaction over the lack of democratic consultation is a crucial factor in opposition to the nuclear issue.

Excluding public preferences via disconnection and lack of communication and ignoring public fears of the process has eroded public sympathy and created dissatisfaction over nuclear energy. The anti-nuclear groups thus accuse responsible bodies of avoiding public scrutiny during the entire process to employ nuclear energy. This prevents the achievement of a greater public consensus and heightens the division between civil society and the nuclear decision-makers.

The "why-not-a-referendum" approach advocated by opponents has also been ignored. According to a recent survey taken by Greenpeace Mediterranean following the Fukushima Nuclear Disaster, 64 percent of respondents stated that they would vote "no" in a possible referendum on having NPPs in Turkey, and more than 86 percent stated that they did not want to live near an NPP. No attempt has been made by public authorities to assess public opinion. Turkey's nuclear future is merely at the mercy of policy-makers (Interview, Melda Keskin, July 30, 2016). Opponents believe it is essential to obtain public consent considering "nuclearization" is a crucial issue beyond any technological or economic matter. More generally, the conjunction between growing criticism and opposition to the nuclear project and citizen preference need to be taken into account to produce a widely-accepted consensus.

Third, attempts by civil society organizations to organize public protests have been suppressed, sometimes violently. Greenpeace's intervention at the first Istanbul Nuclear Power Plants Summit in 2014 supported by the Turkish Ministry of Energy and Natural Resources was suppressed. Nine Greenpeace activists were detained by the police after hoisting a banner that said "Nuclear Disaster Starts Here." Participants of this summit included the license holders of Akkuyu and Sinop NPPs, top-level representatives from the Republic of Turkey's Ministry of Energy and Natural Resources, nuclear suppliers, consultants, public authorities, and Turkish manufacturers willing to invest in nuclear energy. NGO or trade union representatives were not invited. This was not difficult to predict considering government representatives in the energy sector were turning a blind eye to public concern.

There is one more issue pertaining to the nature of the Akkuyu project. The Akkuyu Information Center located in Mersin informs school groups (elementary, middle, and high school) and teachers about nuclear energy and nuclear technology, and the facilities that produce and use it. Nuclear energy is presented as unambiguously good and the sole option for Turkey's energy future. Looking at this issue from the Greenpeace perspective, this has been considered nuclear propaganda given that the reality surrounding nuclear energy in education is not objective, and they argue it should be based on scientific truth (Greenpeace 2015). Explaining nuclear energy and technology to children without its historical 
context, including Chernobyl and Fukushima, and especially Akkuyu which has been such a contested issue, was an issue of the utmost importance to Greenpeace in 2015. To protest this, they launched an online signature campaign that reached more than 23,000 people by July 2016. The main goal of the campaign is to cancel the curriculum in nuclear energy provided by the Ministry of National Education. As also affirmed by the NKP's current spokesperson Erkan Demir, the NKP Mersin sent a petition to the Ministry of National Education's branch in Mersin which requested an investigation into the background of the nuclear project and also demanded organization of panels on nuclear alternatives such as wind and solar energy for students in Mersin. However, these calls were rejected by the authorities, who replied that the necessary information about nuclear energy is given by teachers at school (Interview, Erkan Demir, February 24, 2016).

Such one-sided explanations through nuclear advertising to induce people to agree with nuclear energy development and particularly the Akkuyu project is seen as a violation of educational rights, and has become one of the grievances of the Turkish anti-nuclear groups who claim that this is an unprofessional way for disseminating scientific information. Lack of scientific and objective analysis of nuclear energy at schools neither stimulates the sharing of information in an appropriate way nor promotes the use of national renewable energy sources and energy efficiency technologies.

Fourth, another argument shaping a visible stance toward the project consists of looking abroad and noting which countries are still pursuing nuclear energy, and which have abandoned it in the wake of Fukushima. Anti-nuclear activists put forward the claim that no democracy has continued to pursue nuclear energy. Instead, democratic countries have phased it out as outdated and inferior to other viable alternatives. Only undemocratic ones such as China and Saudi Arabia continue to build NPPs (Interview, Cenk Levi, July 15, 2016). This leads to the question of why Turkey is seeking to acquire nuclear energy when the democratic world is giving it up.

Last but importantly not least, looking at other political parties, it is fair to say that any decision over the Akkuyu NPP in Turkey by the current pro-nuclear government is political rather than raw ideology. Opposing Akkuyu would be framed as being against Turkey's neoliberal policies for economic growth, Russia's privilege, the consequences of the Fukushima Disaster, and more. Therefore, opposition from parties is very limited to leftist and environmentalist parties such as the Turkey Social Democratic Party (CHP), the Greens, and the Left Party of the Future (Yesiller Partisi). This weak opposition is based around a few fierce activist parliamentarians in Mersin from these opposition parties, such as Aytug Atici and Huseyin Camak, and representatives such as Sevil Turan. 


\section{Consequence-Based Explanation of Opposition to the Akkuyu Project in the Wake of Fukushima}

Although all the Turkish anti-nuclear groups were born out of a struggle against the nuclear issue in Turkey, they all went beyond the subject that triggered their formation. Lessons from Fukushima strengthened opposition and made the situation more alarming for states with NPPs. The Fukushima Daiichi nuclear accident was a turning point for Turkish citizens to question the necessity of nuclear power not only in Turkey but also anywhere in the world. The accident drew immediate public attention in 2011 together with the twenty-fifth anniversary of Chernobyl. Fukushima was an alert to assess nuclear technologies around the world and changed the interpretation of the nuclear question in Turkey. The reactors at Chernobyl belonged to the Soviet Union and used outdated technologies. Fukushima, on the other hand, was comprised of pioneering Japanese technology. The accident was a reason to continue the nuclear debate because it showed that an earthquake could destroy anything, even NPPs using the best technologies (Interview, Umit Sahin, July 15, 2016). More generally, after Fukushima, people became less ambivalent over nuclearization and started to question even the advanced Japanese technology, which, until then, had a great reputation in Turkey. Many groups claimed that "even Japan, which is a leading country with its eminent technology and equipment, has failed. How can we trust the Russian state-owned company Rosatom, which has a bad image due to the Chernobyl disaster?"

The nuclear debate continued fiercely and became more crucial with this strong argument. Fukushima has given legitimacy to public skepticism of any NPP. After Fukushima, anti-nuclear groups in Turkey have become more ambitious in organizing mass political mobilization around a concrete argument that "any nuclear reactors can fail as nuclear power is fundamentally unsafe." They spoke more than ever, arguing that this accident proved that an accident can happen anywhere in the world regardless of sophisticated technology. They used this opportunity to relaunch denunciation campaigns about nuclear power to derail the establishment of the Akkuyu NPP. For example, for the members of NKP Mersin, the slogan after Fukushima became “don't let Akkuyu become Fukushima!"

Erdogan's answer to public dissent after Fukushima largely avoided the specific risks posed by nuclear power and focused instead of the inevitability of risks in all walks of life. Erdogan said "in that case, let's not bring gas canisters to our homes, let's not install natural gas, let's not stream crude oil through our country." Experts, activists, and NGOs protested the Prime Minister's playing down of a tragic event and the crucial risks of nuclear power. In light of this attitude, it can be argued that if there was ever a nuclear accident, it would be swept under the carpet given the example of the biggest mine accident in the 
Figure 2. "Don’t Let Akkuyu Become Fukushima"

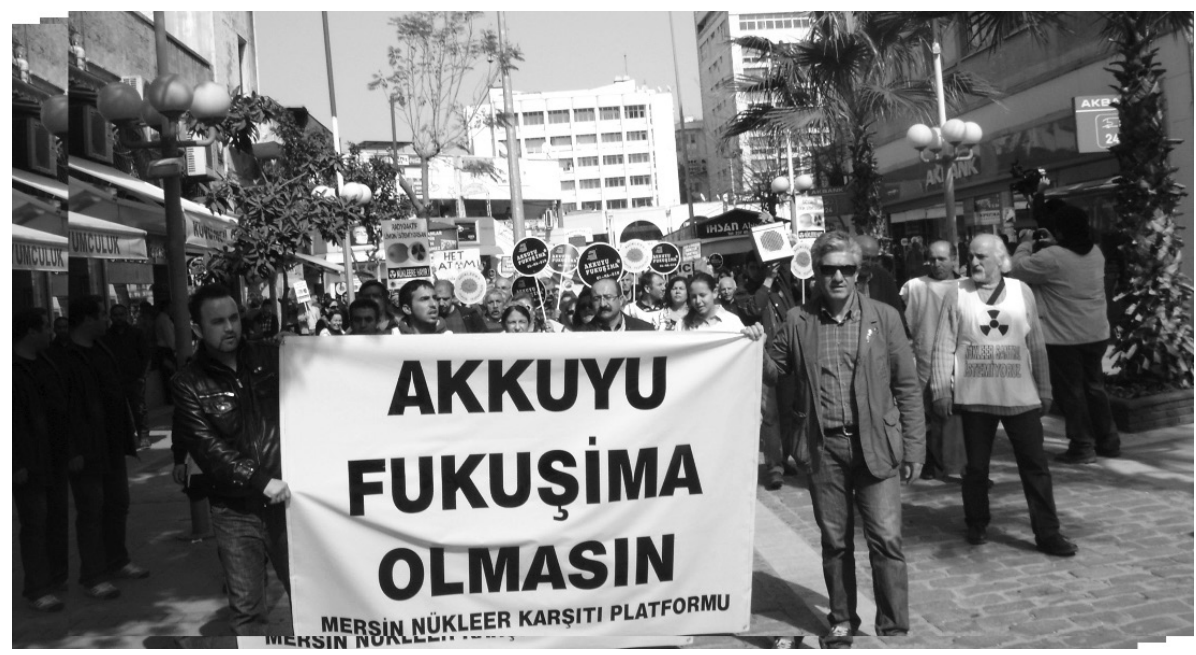

Source: Former Spokesperson for NKP Ms. Sabahat Aslan shared via email on February 24, 2015

history of Turkey at Soma in 2014. Erdogan's response to this tragedy was to say that risks were normal and accidents would happen. In one of his speeches he remarked, "let's please not pretend such incidents do not occur in mines," and continued to say "these are ordinary developments. It is something like labor accidents in literature. This is part of the nature of this business...Security and health regulations had received a pass...Don't protest, just pray." One of the fears surrounding the Akkuyu project is centered on the government's downplaying of "the right to life" through maintaining such discourses and nuclear ignorance. Anti-nuclear groups ask, "who will take responsibility in that case?" They believe that nothing is guaranteed and it is not appropriate to take such risks under these circumstances.

\section{Alternative Engergy-Based Explanation of Opposition to the Akkuyu Project}

A different approach to the nuclear question is based on promoting a transition away from the Akkuyu nuclear project to renewable energies since Turkey has great potential to do so. The anti-nuclear movement claims that demanding possible safer alternatives to reliance on nuclear power in a sustainable way would be the best solution to ensure Turkey's future energy supply. In this way, Turkey would become a self-sufficient country in energy, independent of Russia. Turkey has a very rich renewable energy potential, especially for wind, solar, 
and geothermal. A report prepared by Greenpeace with the European Union Renewable Energy Council demonstrates that Turkey can meet 85 percent of its electricity needs with renewables like wind, solar, and geothermal energies by 2040 (Greenpeace 2014b).

The examination of nuclear energy created a "nuclear exit" in Germany (Ramana 2013, 67). After the Fukushima crisis, the German government formulated a "nuclear phase-out" policy and shut down seven reactors. They committed to an expansion of renewable energy sources by 2022. By doing so they strived to be a role model for other countries and remain an industrial powerhouse (Jahn and Korolczuk 2012). The model for Turkish anti-nuclear activists is Germany, where a strong civil society enabled anti-nuclear groups to take the initiative after Fukushima and convince the government to put forward a plan to phase out nuclear power and focus more on renewable energy policies. Considering Turkey's solar capacity and geographical position (sunshine for 300 days), it is perfectly capable of generating solar energy. Groups often address this issue thorough the concrete example of Germany, asking "why not Turkey?" (Interview, Seyfettin Atar, February 24, 2016).

Another advantage of renewable energy sources, from the point of view of these groups, is that they do not include any international organization or business, nor do they require any extensive security. They are innocuous compared to NPPs which require a review of their compatibility given security concerns. Moreover, renewable energies are less expensive than nuclear power. According to the subsidy program introduced by The Usage of Renewable Energy Sources for Electric Energy Generation for Turkey in 2010, licensed suppliers with a "Renewable Energy Supply Document" are guaranteed the following prices per kWh for a ten year period: wind energy at USD 7.3 cents, geothermal energy at USD 10.5 cents, and solar energy at USD 13.3 cents (Kumbaroğlu 2012, 19). When comparing renewable energy subsidies with Akkuyu (USD 12.35 cents per $\mathrm{kWh}$ in the first fifteen years) including fuel, operations, management, as well as waste management and decommissioning, it can be said that the comparative cost of nuclear energy will be very high (Gürbüz 2012).

Besides, in the aftermath of any possible accident, people might be obliged to pay an "emergency disaster tax" to remedy the situation. After Fukushima, the Japanese government planned to impose such a tax to pay for damage caused by the Fukushima Daiichi NPP. According to my interviews, it is anticipated that the public will be obliged to pay a nuclear tax if an accident takes place.

The question of "why is there no attempt to shift to localized, renewable energy options, focus on sustainable energy policies, and encourage investments in solar, wind, and hydro energy to reduce foreign dependency" has led dissidents to frame this issue as an irrational one since the beginning. In this respect, Greenpeace (2010) proposed a solution by comparing two well-developed regions with Akkuyu-Buyukeceli and the Sinop Inceburun site on the Black Sea through 
a historical perspective. The Alacatı and Bozcaada regions in the west of Turkey have become socio-economically developed after investing in wind and solar energy. They became notable places in terms of tourism and organic agriculture and have proven that sustainable energy alternatives are possible. The report concludes that there has been no such initiative in either Akkuyu-Buyukeceli or Sinop despite their solar and wind capacity as well as potential for tourism. This is due to the fact that these regions have a nuclear shadow of uncertainty hanging over them to the detriment of agriculture and tourism. To make their arguments accessible to the local population, Greenpeace volunteers installed a set of solar panels on the mosque in Büyükeçeli in 2010 to demonstrate how renewable energy could be a viable alternative to the proposed nuclear project. The solar energy has been meeting the power needs of the entire mosque since then. By demonstrating these tangible solutions and findings, especially in the aftermath of Chernobyl and Fukushima, Greenpeace seeks to make the case that Turkey does not need to go nuclear.

In light of all these findings, anti-nuclear groups argue that going nuclear is irrational when considering Turkey's capacity. There is no clear indication that this project is motivated by finding a real solution to energy production. Taking renewable alternatives into account as safer and more affordable, they argue that "Turkey does not need nuclear energy" as the country is not a resource-poor country incapable of covering its energy demand. As for the unified opposition discourse, the need for Turkey is an efficient energy revolution without making "energy need" a matter of trade and national prestige. The questions shaping their arguments on renewables versus nuclear remain: "why is Turkey not ensuring maximum use of renewable energy alternatives" and "why does Turkey not invest in energy alternatives since the Mediterranean Sea is very rich in terms of solar energy?"

\section{Conclusion}

The objections and opposition to nuclear development in Turkey have their own history dating back to the 1970s, which was seen as an emblematic milestone in the fight for environmental justice in Turkey. Starting with the agreement with Russia in 2010 to build the first NPP, Turkey's anti-nuclear struggle regained momentum. Since then, opponents of the project have brought to light its controversial nature with several distinct arguments. The findings show that perceptions of unsophisticated safety and security measures, problematic conditions related to potential seismic activity, and doubts surrounding national security allow the project to be framed as risky. The extreme cost, insufficient information on and legality of waste disposal, and administrative improperness form the core of the aggravated grievances. Ignoring public preference, the 
non-democratic structure of the decision-making process, and the lack of consultation and communication have generated a frame for a fiery political debate. Not only this, opposition groups argue that no lesson has been learned from the Fukushima accident since no attempt has been made to revert from this conflictual and contested construction of nuclear power plants to a more desirable focus on the divergent renewable options.

The persistence of the unanswered questions (such as who would be liable for a nuclear accident) posed by the anti-nuclear groups as well as concerned civilians are the principal explanations for the uncertainties and an unpredictable future surrounding the project. These explanations provide a root in constructing and framing it as an "unsatisfactory, irrational, unsupportable, unfavorable, flawed, unwanted, unsympathetic, stay-away-project, skeptical, and risky" nuclear project by the activists, environmentalists, nuclear opponents, civil society organizations, and others who are completely against the project itself or commercial use of nuclear energy regardless of its intrinsic elements. These people also defined this dissonance as a "nuclear conflict or threat" through doubting all aspects of the project.

From the beginning, they portray "drivers of any nuclear program" as a catastrophic means of producing energy and frame their futuristic scenarios on the Akkuyu project as an "unhappily-ever after" one. After the agreement with Russia and the Fukushima accident, any nuclear project is continually painted as a problematic for them. Distrust in the unsafe nature of Rosatom and inexperience and misgivings in Turkey's infrastructure as a newcomer shape this picture for Akkuyu. At the same time, the government's commitment to the project also remains intact. Therefore, Turkey's intractable nuclear puzzle and love-hate relationship with the nuclear resurgence can be predicated and framed as an unresolved Gordian knot that will not seemingly be cut in the near future.

\section{Appendix: List of Interviewees}

Although all of the interviewees listed below are not cited directly in this article, discussions with all of them helped frame the arguments laid out here.

Sebahat Arslan (former NKP spokesperson, February 24, 2016, Mersin)

Seyfettin Atar (Head of the Chamber of the Electric Engineering, February 24, 2016, Mersin)

Erkan Demir (current NKP spokesperson, February 24, 2016, Mersin)

Fikret Adaman (Professor at Bogazici University, March 5, 2016, Istanbul)

Filiz Yavuz (Author and activist, March 6, 2016, Istanbul; Second Interview on August 4, 2016 via email)

Ümit Şahin (Istanbul Policy Center, March 6, 2016, Istanbul) 
Pinar Demircan (Project Manager at nükleersiz.org, March 7, 2016, Istanbul) Hayrettin Kilıç (Nuclear physicist, peace activist and environmentalist, April 16, 2016, via email)

Melda Keskin (Former Coordinator of Greenpeace' Energy Campaign, via email on April 18, 2016, and in person on July 30, 2016)

Arif Künar (energy expert and activist, April 21, 2016, via email)

Aytuğ Atıcı (parliamentarian and anti-nuclear activist, May 2, 2016, via email)

Cenk Levi (former energy campaigner of Greenpeace, July 15, 2016, via Skype)

Arif Ali Cang1 (lawyer for the Greens and the Left Party of the Future, independent activist, August 12, 2016, via email)

Özgür Gürbüz (activist and blogger, August 4, 2016, via email)

\section{References}

Atici, Aytug. 2015. "Akkuyu and Sinop: The Struggle on Nuclear Power Plants in Turkey. International Physicians for the Prevention of Nuclear War." http://www.ippnw.eu/ commonFiles/pdfs/Internationales/Belgrade2015/Atici.pdf (accessed October 30, 2018).

Campaign for Nuclear Disarmament. 2006. “The Links between Nuclear Power and Nuclear Weapons.” https://cnduk.org/resources/links-nuclear-power-nuclearweapons/ (accessed October 20, 2018).

Della Porta, Donatella, and Mario Diani. 2006. Social Movements: An Introduction. Oxford: Blackwell.

Demircan, Pinar. 2015. “Turkey's Nuclear Obsession Is Dangerous and Entirely Misplaced.” Dianuke, October 27. http://www.dianuke.org/turkey-nuclear-obsession-dangerousand-entirely-misplaced-pinar-demircan/ (accessed October 20, 2018).

DeRosa, Tom. 2015. "Renewables vs. Nuclear: Do We Need More Nuclear Power?" Renewable Energy World, April 18. https://www.renewableenergyworld.com/ugc/ articles/2015/04/renewables-vs-nuclear-do-we-need-more-nuclear-power.html (accessed October 20, 2018).

Digges, Charles. 2013. "Is Koodankulam Unsafe?: Russian Supplier Arrested for Corruption and Substandard Equipment.” Dianuke, April 8. http://www.dianuke.org/ is-koodankulam-unsafe-russian-supplier-arrested-for-corruption-and-substandardequipment/ (accessed October 20, 2018).

Doğan, Yalçın. 2015. "Beloved Akkuyu, for the sake of what?” Hurriyet Daily News, April 15. http://www.hurriyetdailynews.com/opinion/yalcin-dogan/beloved-akkuyu-forthe-sake-of-what-81055 (accessed October 20, 2018).

EDAM (Centre for Economic and Foreign Policy Studies). 2012. "Turkey and Tactical Nuclear Weapons: A Political Love Affair.” November 1. http://edam.org.tr/en/turkeyand-tactical-nuclear-weapons-a-political-love-affair/ (accessed October 20, 2018).

Greenpeace. 2010. "Nukleer Enerji: Nükleer Tehdidin Karşısında Sürdürülebilir Kalkınma" [Nuclear Energy: Sustainable Development under the Nuclear Threat]. https:// www.greenpeace.org/turkey/Global/turkey/report/2010/4/nukleer-enerji-skobt.pdf 
(accessed October 30, 2018).

Greenpeace. 2011. “Fukushima 2011; Akkuyu 2020." [in Turkish.] March 22. http:// www.greenpeace.org/turkey/tr/news/blog/nukleer/fukushima-2011-akkuyu-2020/ blog/36116/ (accessed October 20, 2018).

Greenpeace. 2014a. "Akkuyu Nükleer Santrali ÇED Raporu Hâlâ Eksiklerle Dolu” [Akkuyu Nuclear Power Plant CED Report is still full of deficiencies]. July 7. http://www. greenpeace.org/turkey/tr/news/ced-raporu-hala-eksiklerle-dolu-070714/ (accessed October 20, 2018).

Greenpeace. 2014b. "Nükleer Santraller Zirvesinde Greenpeace Eylemi” [Greenpeace Action in the Nuclear Summit]. May 30. http://www.greenpeace.org/turkey/tr/news/ nukleer-santraller-zirvesinde-greenpeace-eylemi-300514/ (accessed October 20, 2018).

Greenpeace. 2015. “Okullarda Nükleer Propagandaya Hayır.” [No to Nuclear Propaganda at Schools]. http://imza.greenpeace.org/nukleermasallar (accessed October 26, 2018).

Greenpeace Hungary. 2014. "Rosatom Risks: Exposing the Troubled History of Russia's State Nuclear Corporation.” October 6. https://www.greenpeace.org/hungary/hu/ hirek/publikaciok/Rosatom-risks/ (accessed October 20, 2018).

Guigni, Marco. 1998. "Was it Worth the Effort? The Outcomes and Consequences of Social Movements." Annual Review of Sociology 24: 371-393.

Gürbüz, Özgür. 2012. "Nükleer Santral Kaça Patlar?” [How Much Does a Nuclear Power Plant Cost?] İkibin50, November 8. http://ozgurgurbuz.blogspot.com/2012/12/ nukleer-santral-kaca-patlar.html (accessed October 30, 2018).

Gürbüz, Özgür. 2016. "Nükleer Güvenlik Zirvesinde Nükleer Terör Konuşulacak" [Nuclear Terrorism will be discussed at the Nuclear Security Summit]. April 1. https://www.birgun.net/haber-detay/nukleer-guvenlik-zirvesi-nde-nukleer-terorkonusulacak-107880.html (accessed October 20, 2018).

Holt, Mark, and Anthony Andrews. 2014. "Nuclear Power Plant Security and Vulnerabilities." Congressional Research Service, January 3. https://fas.org/sgp/crs/ homesec/RL34331.pdf (accessed October 20, 2018).

Jahn, Detlaf, and Sebastian Korolczuk. 2012. "German Exceptionalism: The End of Nuclear Energy in Germany!” Environmental Politics 21 (1): 159-164.

Jarvis, Darryl S.L. 2007. "Theorizing Risk: Ulrich Beck, Globalization and the Rise of the Risk Society." Lee Kuan Yew School of Public Policy, National University of Singapore. http://www.forschungsnetzwerk.at/downloadpub/risk_RR3_u_Beck.pdf (accessed October 20, 2018).

Kitscheld, Herbert P. 1986. "Political Opportunity Structures and Political Protest: AntiNuclear Movements in Four Democracies." British Journal of Political Science 16 (1): 57-85.

Koopmans, Ruud, and Jan Willem Duyvendak. 1995. "The Political Construction of the Nuclear Energy Issue and Its Impact on the Mobilization of Anti-Nuclear Movements in Western Europe." Social Problems 42 (2): 235-251.

Kumbaroğlu, Gürkan. 2012. "Nükleer Enerjiye Geçişte Türkiye Modeli II” [The Turkish Model for Transition to Nuclear Energy II]. EDAM, December 1. http://edam.org.tr/ nukleer-enerjiye-geciste-turkiye-modeli-ii/ (accessed October 26, 2018).

Martin, Brian. 2007. “Opposing Nuclear Power: Past and Present." Social Alternatives 26 (2): 43-47. 
McCarthy, John D., and Mayer N. Zald. 1977. "Resource Mobilization and Social Movements: A Partial Theory." American Journal of Sociology 82 (6): 1212-1241.

Netzer, Nina, ed. 2011. The End of Nuclear Energy: International Perspectives after Fukushima. Bonn: Friedrich Ebert Stiftung.

Nuclear Energy Project Implementation Department. 2018. "Akkuyu Nükleer Güç Santrali Projesi İçin Neden Rusya Federasyonu Seçildi?” [Why has the Russian Federation been chosen for the Akkuyu Project?]. Accessed October 20, 2018, https://nepud. enerji.gov.tr/tr-TR/Bilgi-Bankasi/Akkuyu-Nukleer-Guc-Santrali-Projesi-Icin-NedenRusya-Federasyonu-Secildi.

Ozcetin, Burak, and Mustafa Ozer. 2015. “The Current Policy Environment for Civil Society in Turkey." Johns Hopkins University Center for Civil Society Studies, Comparative Nonprofit Sector Working Paper No. 53, January. http://ccss.jhu.edu/ wp-content/uploads/downloads/2015/02/Turkey_CNP_WP53_2015_FINAL.pdf (accessed October 20, 2018).

Pianta, Mario, Anne Ellersiek, and Peter Utting. 2012. "How Can Activism Make Change Happen?" In Global Justice Activism and Policy Reform in Europe: Understanding When Chang Happens, eds. Peter Utting, Mario Pianta, and Anne Ellersiek, 524-544. London: Routledge.

Radikal. 2015. "Akkuyu Nükleer Santralı ÇED Raporu’nda Sahte Imza Skandalı." [The scandal of fake signatures in the Akkuyu NPP - CED Report]. January 12. http:// www.radikal.com.tr/turkiye/akkuyu-nukleer-santrali-ced-raporunda-sahte-imzaskandali-1270315/ (accessed October 20, 2018).

Ramana, M. V. 2013. Nuclear Policy Responses to Fukushima: Exit, Voice, and Loyalty. Bulletin of the Atomic Scientists, March 1. https://thebulletin.org/2013/03/nuclearpolicy-responses-to-fukushima-exit-voice-and-loyalty/ (accessed October 20, 2018).

Schön, Donald A., and Martin Rein. 1994. Frame Reflection: Towards the Resolution of Intractable Policy Controversies. New York: Basic Books.

Statistics Portal. 2015. "Electricity Prices by Country in 2015 (in U.S. Dollars per Kilowatt Hour).” https://www.statista.com/statistics/477995/global-prices-of-electricity-byselect-countr (accessed October 26, 2018).

TAEK (Turkish Atomic Energy Authority). 2012. "TAEK ve Nükleer Santral Lisanslama" [Turkish Atomic Energy Authority and Licensing Nuclear Power Plant]. October 8. http://www.taek.gov.tr/tr/2016-06-09-00-43-55/44-akkuyu-nukleer-guc-santrali/ 695-taek-ve-nukleer-santral-lisanslama.html (accessed October 20, 2018).

TEMA. 2014. "Huge Mistake: Akkuyu Nuclear Power Plant.” http://tema.org.tr/web_ 14966-2_2/entitialfocus.aspx?primary_id=1341\&target=categorial $1 \&$ type $=2 \&$ detail= single (accessed October 20, 2018).

Tilly, Charles. 1998. "Social Movements and (All Sorts of) Other Political Interactions Local, National, and International - Including Identities." Theory and Society 27 (4): 453-480.

Trenin, Dmitri. 2016. "Russia in the Middle East: Moscow's Objectives, Priorities, and Policy Drivers.” Carnegie Endowment for International Peace, April 5. https:// carnegieendowment.org/files/03-25-16_Trenin_Middle_East_Moscow_clean.pdf (accessed October 20, 2018).

Udum, Şebnem. 2010. "Understanding the Nuclear Energy Debate in Turkey: Internal and External Contexts." Ph.D. Dissertation, University of Bilkent. http://www.thesis. 
bilkent.edu.tr/0003961.pdf (accessed October 20, 2018).

Walsh, Edward J. 1981. "Resource Mobilization and Citizen Protest in Communities around Three Mile Island." Social Problems 29 (1): 1-21.

World Nuclear Association. 2018. "Nuclear Power in Turkey." June. http://www.worldnuclear.org/information-library/country-profiles/countries-t-z/turkey.aspx (accessed October 20, 2018).

Yeşil Gazete. 2015. "Akkuyu Nükleer Santrali dolgu alana kurulacak!” [Akkuyu Nuclear Power Plant will be set up in an Appropriate Place]. February 26. https://yesilgazete. org/blog/2015/02/26/akkuyu-nukleer-santrali-dolgu-alana-kurulacak/ (accessed October 20, 2018).

Pinar Temocin studied philosophy in Turkey and Germany and political science in France. She is doing her Ph.D. in Peace Studies and Development Science at Hiroshima University, Japan, working on anti-nuclear activism in Japan and South Korea in the post-Fukushima era. She is currently a visiting researcher in the Graduate School of Environmental Studies at Seoul National University, South Korea. Her research interests include environmental activism, civil society, social movements, community development, etc. 
